УДК 378.147:372.8004

DOI:

Оксана Ісаєва, доктор педагогічних наук, професор кафедри педагогіки та інноваційної освіти Національного університету “Львівська політехніка", доиент кафедри латинської та іноземних мов Львівського національного медичного університету імені Данила Галицького Беата Кушка, кандидат філологічних наук, доцент кафедри іноземних мов Національного університету “Львівська політехніка"

\title{
ФУНДАМЕНТАЛІЗАЦІЯ ЯК ВАЖЛИВА СКЛАДОВА ВИЩОЇ ТЕХНІЧНОЇ ОСВІТИ
}

У статті обтрунтовано особливості фундаменталізації вищої освіти, яка передбачає оновлення підходу до якості освіти в сучасних умовах пандемії ковід-19, формування особистості та затребуваних компетентностей. Тому створення умов для виховання і формування сучасного фахівия з науковим мисленням, внутрішньою потребою саморозвитку та самоосвіти упродовж життя вважається фундаментальним завданням для вищої технічної освіти.

Сучасний фахівець повинен не лише засвоювати подані знання, але й володіти методологією пошуку нового, синтезування і оброблення здобутого чи імплементація його у виробництво. Фундаменталізація освіти також передбачає, аби кожен випускник закладу вищої освіти мав чітко сформульовану мету, вмів аналізувати, діагностувати, синтезувати і лите тоді презентувати здобуту інформачію.

Ключові слова: фундаменталізація; вища технічна освіта; якість освіти; професійна освіта; сучасний фахівець.

Puc. 1. Лim. 8.

Oksana Isayeva, Doctor of Sciences (Pedagogy), Professor of the Pedagogy and Innovative Education Department of Lviv Polytechnic National University; Associate Professor of the Latin and Foreign Languages Department, Lviv Danylo Halytsky National Medical University

Beata Kushka, Ph.D.(Philology), Associate Professor of the Foreign Languages Department of Lviv Polytechnic National University

\section{FUNDAMENTALIZATION AS AN IMPERATIVE ELEMENT OF HIGHER TECHNICAL EDUCATION}

The article substantiates features of fundamentalization of higher education, which provide for an updated approach to the quality of education in modern conditions of the COVID-19 pandemic, personality formation and in-demand professional competencies. Current situation creates such conditions that quality education cannot be obtained without research activities as the basis for the formation of divergent thinking in students, the ability to self-education, the ability to work in a team, motivation for continuous professional improvement, the development of abilities to independently create new ideas and creative thinking. Consequently, the creation of conditions for nurturing and formation of a modern specialist with scientific thinking, internal need for self-development and selfeducation throughout life is considered to be a fundamental task for higher technical education.

Fundamentalization involves the application of an individual approach to the student; the formation of his worldview; stimulation of students' and teachers' academic mobility; adaptation to constant changes in profession and life; training of competitive specialists with basic competencies and relevant qualities.

Fundamentalization of education also suggests that each graduate of a higher educational institution must have a clearly formulated goal, be able to analyze, diagnose, synthesize and only then present the information obtained.

The reform of higher education provides for the organization of the educational process according to the updated content, special attention is focused on self-study and independent work, distance learning and new and more effective teaching methods. A modern specialist must not only master the knowledge presented, but also possess the methodology of searching for something new, synthesizing and processing what has been obtained or implementing it into the manufacture.

Keywords: fundamentalization; higher technical education; quality of education; professional education; modern specialist.

$\Pi$ остановка проблеми у загальному вигляді. Транснаціональні культурні, економічні й інформаційні потоки

змінюють роль вищої освіти, висуваючи підвищені вимоги до формування аналітичних та інформаційних здібностей студентів. Ці умови 
репрезентують освіту як найважливіший ресурс розвитку особистості, їі креативності та інноваційного мислення і як один з першорядних чинників ефективності та конкурентоспроможності майбутнього фахівця. Тому фундаменталізація освіти розглядається невід'ємною складовою реорганізації закладів вищої освіти і оновлення змісту освітніх послуг.

Сьогодення диктує такі умови, що якісну освіту неможливо здобути без науководослідницької діяльності як основи формування у студентів дивергентного мислення, здатності до самоосвіти, вміння працювати у команді, мотивації до постійного професійного удосконалення, розвитку здібностей самостійно створювати нові ідеї й креативно мислити. Власне сучасний фахівець повинен не лише засвоювати подані знання, але й володіти методологією пошуку нового, синтезування і оброблення здобутого чи імплементації його у виробництво. Отож, як наголошує дослідниця.

I. Шоробура, що “визначальними напрямами розвитку вищої школи є моральна довершеність майбутніх фахівців, надійний знаннєвий багаж, високий рівень інтелектуального розвитку, володіння методами самостійної пізнавальної діяльності, прагнення досягти успіху й уміння будувати міжособистісні стосунки" [7].

Тобто мобільність у сфері вищої технічної освіти спрямована на отримання нових теоретичних знань, практичних навичок i культурної компетенції щодо особливостей обміну досвідом. Тому виняткової уваги заслуговує твердження Рідінгса про те, що “питання, яке стоїть перед Університетом, полягає не в тому, як перетворити наявний Інститут в притулок Мислення, а в тому, як мислити в Інституті, розвиток якого робить Мислення все більш складним, все менш необхідним" [6, 276].

Актуальність розвідки полягає у тому, що сучасні умови вимагають оновленого підходу до якості вищої технічної освіти й рівня професійної компетентності фахівців у кризових умовах пандемії ковід-19.

Мета дослідження - схарактеризувати перспективи застосування конструктивних ідей щодо фундаменталізації вищої технічної освіти.

Відповідно до мети дослідження визначено такі завдання:

- окреслити сутність фундаменталізації професійної освітньої підготовки майбутніх фахівців технічних галузей;

- визначити шляхи імплементації оновленої парадигми вищої технічної освіти з огляду на затребуваність фахівця нової генерації.
Аналіз останніх досліджень і публікацій. Проблеми фундаменталізації освіти широко обговорюються науковцями різних галузей, зокрема методологічну основу фундаменталізації професійної освіти та організацію освітнього процесувивчали Н. Бідюк, Г. Васьківська, Т. Вдовичин, М. Дмитриченко, Б. Камінський, С. Клепко, I. Козловська, Е. Лузик, І. Мельничук, Л. Пуховська, С. Романова, Л. Романишина; аспекти фундаменталізації професійної підготовки фахівців у контексті європейського освітнього простору розглядали М. Дмитриченко, О. Русановський, В. Сидоренко, Г. Терещук; фундаменталізацію вищої освіти та університетського навчання зокрема досліджували І. Гавриляк, С. Гончаренко, М. Жалдак, С. Семерікова, С. Сисоєва, Я. Фруктова, Г. Шатковська.

Виклад основного матеріалу й обгрунтування отриманих результатів дослідження. Фундаменталізація вищої освіти передбачає оновлення підходу до якості освіти в сучасних умовах пандемії ковід-19, формування особистості та затребуваних сьогоденням компетентностей. Тому створення умов для виховання і формування сучасного фахівця 3 науковим мисленням, внутрішньою потребою саморозвитку та самоосвіти упродовж життя вважається фундаментальним завданням для вищої технічної освіти. Уважаємо слушним твердження дослідниці О. Язвінської, яка засвідчує, що “фундаменталізація професійної освіти відображає загальні закономірності розвитку, руху та функціонування освітньої сфери й розкривається в процесі виконання фахівцем професійної діяльності”. Також науковець впевнено зауважує, що фундаменталізація професійної підготовки технічних спеціальностей забезпечить у майбутньому відмінну фахову компетентність та успішне пристосування випускника університету до динамічних умов суспільства [8, 34].

Як зазначається у Національній стратегії розвитку освіти в Україні упродовж 2012 - 2021 pр., що “якісна освіта $є$ необхідною умовою забезпечення сталого демократичного розвитку суспільства, консолідації усіх його інституцій, гуманізації суспільно-економічних відносин, формування нових життєвих орієнтирів особистості" [4]. Отож, визначною передумовою безперервності та наступності професійної освіти розглядається структура фундаменталізації, яка включає створення оновлених курсів відповідно до силабусів чи програм, їх зміст повинен наповнюватися узагальненими знаннями з метою забезпечення поглибленої теоретичної та 
практичної підготовки, формування особистісної і професійної культури, закладення основ креативності чи наукового мислення і розвитку затребуваних компетенцій. Власне, таким чином, зміниться якість вищої технічної освіти.

Отож, поділяємо слушне твердження науковця Е. Короткова [4], що якість освіти - це комплекс характеристик, компетентностей і професійної свідомості, які відображають здатність фахівця провадити професійну діяльність відповідно до вимог сучасного етапу розвитку економіки, на визначеному рівні ефективності та професійного успіху. Уважаємо, що сучасні завдання фундаменталізації вищої технічної освіти розглядаються як:

- формування університетського середовища;

- залучення до науково-дослідної роботи;

- розвиток критичного і креативного мислення;

- закладення основ самоаналізу;

- уміння працювати в команді і швидко приймати рішення;

- закладення основ рефлексивного мислення;

- вміння обирати стратегію і тактику професійної поведінки;

- бажання навчатися упродовж життя;

- самовдосконалення і поліпшення якості життя.

Варто зауважити, що важливою складовою фундаменталізації вищої технічної освіти $є$ системний підхід щодо впровадження інформаційно-комунікаційних технологій, академічна доброчесність, застосування сучасних методів викладання дисциплін, акцент на наукову роботу студентів тощо. Однак, слід наголосити, що “окремі теоретичні підходи до фундаменталізації фахової підготовки принципово не сумісні з існуючою системою професійної освіти. Вони припускають корінні зміни парадигми освіти, її змісту, структури, організаційних форм та методів, що веде до неузгодженостей в традиційній вищій школі” [2, 177]. Тому варто поєднувати традиційні та інноваційні методи навчання у вишах, адже наші спеціалісти вважаються найкращими у Європейському просторі.

Оскільки фундаменталізація освіти передбачає цілісні і глибинні знання в усіх сферах діяльності за рахунок міжпредметної інтеграції, тому “фундаменталізація професійної підготовки стосується усіх елементів та складових освіти: цілей, змісту, процесу, методів, засобів, форм, результатів тощо. Однак провідна роль відводиться фундаменталізації освітнього змісту навчальних дисциплін” [1]. Власне фундаменталізація вищої технічної освіти забезпечить високу результативність в освітній, а в майбутньому і у професійній діяльності.

Загальновідомо, що реформа вищої освіти передбачає організацію освітнього процесу за оновленим змістом, особлива увага зосереджується на самостійній роботі, дистанційному навчанні та нових і більш дієвих методах викладання. Оновлення змісту навчальних дисциплін та науково-методичного забезпечення освітнього процесу також відіграє важливу роль у процесі фундаменталізації професійної освіти. Одначе науковець

А. Колот пропонує, що фундаменталізація не претендує на збільшення кількості навчальних годин, проте ставить перед університетською освітою принципово нові цілі та завдання, спрямовані на формування професійного мислення й потребу в саморозвитку та самоосвіті $[3,13]$.

Варто наголосити, що фундаментальними $є$ гуманістичні цінності вищої освіти, надання можливості індивіду виявити свій талант чи реалізувати творчий потенціал як у процесі навчальної, так і професійної діяльності; також використання усіх імовірних ресурсів для досягнення успіху та вміння знайти оптимальний варіант, який уможливлює при мінімальних зусиллях досягати максимального результату. Забезпечення високої результативності у професійній діяльності майбутніх фахівців повинно відбуватися поетапно, починаючи з навчання у виші, зосереджуючи увагу на майбутній діяльності відповідно до засад фундаменталізації.

Уважаємо, що особливої уваги заслуговує студентоцентричний підхід до навчання, який передбачає антропологічний, герменевтичний, діяльнісний, індивідуальний, культурологічний, особистісноорієнтований, онтологічний, системний і цілісний підходи, що акцентують увагу на проєктуванні, синтезуванні, конструюванні, моделюванні та інтеграції здобутої інформації. Тобто, актуалізація внутрішніх ресурсів студентів забезпечує розвиток критичного мислення, формування впевненості у власних знаннях, подолання стереотипів, які перешкоджають досягненню успіху; усвідомлення алгоритмів своєї поведінки, що нівелюють цей успіх. Також сучасні умови зростаючої конкуренції потребують фахового спеціаліста високого рівня, його фундаментальної компетентності в усіх сферах життя і праці. Саме тому фундаменталізація освіти “забезпечується доцільним поєднанням онтологічного, гносеологічного та аксіологічного підходів до підготовки майбутніх працівників" [5]. Тобто, освіта проходить етап фундаменталізіції, якщо вона базується на міжпредметній інтеграції 
i забезпечує грунтовні знання та базові компетенції випускників у практичній діяльності. Отож, пропонуємо власне наповнення моделі фундаменталізації технічної освіти, яке представлено на рисунку 1.

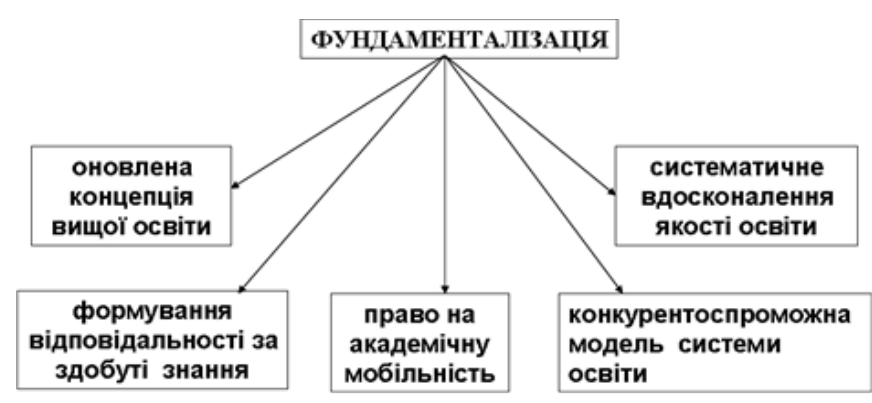

Рис. 1. Схема складових моделі фундаменталізації

На основі аналізу науково-педагогічної літератури, можна узагальнити, що фундаменталізація передбачає застосування індивідуального підходу до студента; формування його світогляду; стимулювання академічної мобільності студентів та викладачів; урахування бажань, потреб та сподівань студента; адаптація до постійних змін у професії і житті; підготовка конкурентоспроможних фахівців з базовими компетенціями і відповідними якостями. Фундаменталізація освіти також передбачає, аби кожен випускник закладу вищої освіти мав чітко сформульовану мету, вмів аналізувати, діагностувати, синтезувати i лише тоді презентувати здобуту інформацію.

Уважаємо, що процес зміни якості вищої освіти на основі принципу іiі фундаменталізації передбачає також упровадження STEM-освіти у вишах 3 огляду на майбутню професійну діяльність, оскільки важливе значення має практичне застосування здобутих знань, тобто вміння реалізувати теоретичні знання на практиці. Стратегія особистісного та професійного розвитку студенів повинна базуватися на суб'єктсуб'єктних стосунках і найсучасніших наукових дослідженнях. Саме тому випереджальна інноваційна освіта уможливлює і доступ до інноваційно-інвестиційних проєктів, методології науки чи практики проведення прикладних досліджень тощо.

Висновок. Фундаменталізація вищої технічної освіти передбачає базові знання, сформовані в єдину “картину світу" за допомогою міжпредметної інтеграції. Професійне мислення розглядається як необхідна складова реформованої вищої технічної освіти, відбувається спрямування її на сумарні й універсальні знання, на формування особистісної й професійної культури особистості як фахівця, на розвиток узагальнених способів мислення й практичної діяльності в сучасних умовах. Динамічність та мобільність вважаються невід'ємними складовими освітньої фундаменталізації.

Проте можливе зниження якості професійної освіти, оскільки існує суперечливість реформ щодо національних цінностей, освітніх традицій чи узгоджених практик, які вважаються провідними острахами щодо швидкої імплементації засад фундаменталізації.

Перспективу подалыших досліджень вбачаємо у формуванні базових компетенцій у фахівців технічних закладів вищої освіти на основі фундаменталізації.

\section{ЛІТЕРАТУРА}

1. Васьківська Г. Фундаменталізація змісту освіти у старшій школі: теорія і практика. Рідна школа. № 3. (2012). C. 25-30.

2. Гончаренко С. У. Фундаментальність чи вузький професіоналізм. Дидактика професійної школи : зб. наук. пр. Інститут педагогіки і психології проф. освіти АПН України. Вип. 1. (2004). С. 177-184.

3. Колот А. М. Вища освіта як чинник формування людського капіталу: сучасний стан, тенденції розвитку. Вісник Прикарпатського університету. Економіка. Вип. 4. (2007). С. 12-16.

4. Коротков Е. Концепція якості освіти. Освіта.иа. 05.07.2006. Режим доступу: http://osvita.ua/school/ manage/general/1342/

5. Мельничук I. М. Філософсько-методологічні засади професійної підготовки майбутніх фахівців соціономічних професій. Медична освіта. № 3. (2012). C. 55-60.

6. Ридингс Б. Университет в руинах / пер. с. англ. А. M. Корбута. (2010). 304 c. URL: http://www.gazeta.ru/ politics/2009/05/18 a 2987620.shtml

7. Шоробура І. Концептуальні напрями розвитку вищої освіти в Україні у контексті європейської інтеграції. Молодь і ринок № 8(175). (2019). С. 28-31.

8. Язвінська О. М. Проблема професійної мобільності сучасного фахівця в контексті фундаменталізації професійної підготовки. Вісник національного транспортного університету. № 24 (1). (2011). C. 32-36.

\section{REFERENCES}

1. Vaskivska, G. (2012). Fundamentalizaciya zmistu osvity u starshij shkoli: teoriya i praktyka [Fundamentalization of the content of education in high school: theory and practice]. Native school. No. 3. pp. 25-30. [in Ukrainian].

2. Honcharenko, S. U. (2004). Fundamentalnist chy vuzkyy profesionalizm [Fundamentality or narrow professionalism]. Didactics of vocational school: collection of scientific work. Institute of Pedagogy and 
Psychology of the Academy of Pedagogical Sciences of Ukraine. Vol. 1. pp. 177-184. [in Ukrainian].

3. Kolot, A. M. (2007). Vyshcha osvita yak chynnyk formuvannya lyudskoho kapitalu: suchasnyy stan, tendentsiyi rozvytku [Higher education as a factor in the formation of human capital: current status, development trends]. Bulletin of the Precarpathian University. Economy. Vol. 4.pp. 12-16. [in Ukrainian].

4. Korotkov, E. Kontseptsiya yakosti osvity [The concept of quality education]. Osvita.ua. 05.07.2006. Available at: http://osvita.ua/school/manage/general/ 1342/ [in Ukrainian].

5. Melnychuk, I. M. (2012). Filosofsko-metodolohichni zasady profesiynoyi pidhotovky maybutnikh fakhivtsiv sotsionomichnykh profesiy [Philosophical and methodological principles of professional training of future specialists of socionomic professions]. Medical education. No. 3. pp. 55-60. [in Ukrainian].
6. Ridings, B. (2010). Universitet $\mathrm{v}$ ruinakh [University in ruins]. Translated from English A. M. Korbuta. 304 p. Available at: http://www.gazeta.ru/politics/2009/05/ 18_a_2987620.shtml [in Russian].

7. Shorobura, I. (2019). Kontseptualni napryamy rozvytku vyshchoyi osvity v Ukrayini u konteksti yevropeyskoyi intehratsiyi [Conceptual directions of higher education development in Ukraine in the context of European integration]. Youth and the market. No. 8(175). pp. 28-31. DOI: https://doi.org/10.24919/23084634.2019.179333 [in Ukrainian].

8. Yazvinska, O. M. (2011). Problema profesiynoyi mobilnosti suchasnoho fakhivtsya $\mathrm{v}$ konteksti fundamentalizatsiyi profesiynoyi pidhotovky [The problem of professional mobility of a modern specialist in the context of fundamentalization of professional training]. Bulletin of the National Transport University. No. 24 (1). pp. 32-36. [in Ukrainian].

Стаття надійшла до редакції 17.03.2021

\section{УДК 378.147:615.8}

DOI:

Катерина Павелків, доктор педагогічних наук, дочент, професор кафедри іноземних мов Рівненського державного гуманітарного університету Олег Чепурка, здобувач ступеня доктора філософіі Рівненського державного гуманітарного університету

\section{ЗДОРОВ'ЯЗБЕРЕЖУВАЛЬНА КОМПЕТЕНТНІСТЬ МАЙБУТНЬОГО ФАХІВЦЯ- ФІЗІОТЕРАПЕВТА: НОРМАТИВНО-ДЕФІНІТИВНИЙ АНАЛІЗ}

У статті представлено результати застосування нормативно-дефінітивного підходу до питань формування здоров'язбережувальної компетентності майбутніх фахівиів-фізіотерапевтів відповідно до вітчизняних та міжнародних освітніх документів, насамперед Світової Конфедерації фізичної терапї та Української Асоціачї̈ фізичних терапевтів. На підставі аналізу змісту українських та міжнародних документів про підготовку фахівиів-фізіотерапевтів з 'ясовано зміст основних дескрипторів, шчо визначають належний рівень професійної компетентності фахівців-фізіотерапевтів на бакалаврському та магістерському рівнях підготовки. Представлено визначення професійної компетентності майбутнього фахівия-фізіотерапевта; проаналізовано його основні професійні компетенції (розуміння концепції знань; клінічні, міжособистісні, технічні навички; навички комплексного розв'язання професійних проблем та клінічної очінки), їх здоров 'язбережувальний зміст; здійснено класифікацію професійних компетенцій фахівияфізіотерапевта та обтрунтовано їх співвідношення з його здоров 'язбережувальною компетентністю.

Ключові слова: професійна компетентність; здоров'язбережувальна компетентність; фахівецьфізіотерапевт; дескриптори.

Рис. 1. Табл. 1. Ліm. 21.

Kateryna Pavelkiv, Doctor of Sciences (Pedagogy), Associate Professor, Professor of the Foreign Languages Department, Rivne State University of Humanities Oleh Chepurka, Applicant for the degree of Doctor of Philosophy,

Rivne State University of Humanities

\section{HEALTH KEEPING COMPETENCE OF FUTURE SPECIALIST IN PHYSICAL THERAPY: NORMATIVE AND DEFINITIVE ANALYSIS}

The article presents the results of application of normative and definitive approach to the problems of formation health keeping competence of future specialists in physical therapy according to domestic and international documents in education, in particular World Confederation of Physical Therapy and Ukrainian Association of Physical Therapy. On the basis of content analysis of Ukrainian and international documents of training specialists in physical therapy the content of main descriptors is discovered, which define appropriate level of professional 